Włodzimierz Karaszewski

ORCID: https://orcid.org/0000-0002-8351-4589

The Nicolaus Copernicus University in Toruń, Poland

\title{
Awarding the Holy Father John Paul II an honoris causa doctorate from the Nicolaus Copernicus University in Toruń
}

A petition to award the Holy Father John Paul II an honoris causa doctorate from the Nicolaus Copernicus University in Torun (UMK) was presented by Rev. Professor Jerzy Bagrowicz, the Dean of the Faculty of Theology in May 2003 at the sitting of the University Development Committee. John Paul II's outstanding merits in the contemporary world and all hiscontributions, as an eminent scholar and author, to science and culture are well-known. Therefore, nobody demanded a more substantial justification of the petition. Members of the Committee supported it with sincere enthusiasm, acknowledging that the Holy Father's acceptance of an honoris causa doctorate from the UMK would be an honour of profound significance and at the same time it would lend class to the celebrations of the sixtieth anniversary of the university foundation. As early as the Committee sitting, Professor Jan Kopcewicz, the Rector, commissioned Rev. Professor Bagrowicz to take the necessary measures and efforts to check the position of the Church authorities in that respect but primarily to get an answer to the question of how likely it is that the Holy Father will accept the degree. The legitimacy of that question was connected first of all with the Pope's poor health. The Rector, and similarly other Committee members, realizing the value of each moment of the Pope's life, which was nearing the end, for the Church and the world, voiced serious doubts as to whether it could be expected that some of those moments would be offered to the university. 
After a couple of months, good news arrived. The Holy Father agreed to the commencement of the doctoral degree award procedure. At the same time, it was agreed that the degree ceremony could take place in the Vatican in November 2004. The time was scarce and the standard course of action was impossible.

The formal procedure was commenced by unanimous approval of the petition to award John Paul II an honoris causa degree of UMK, presented by the Board of the Faculty of Economic Sciences and Management. The approval was given at the Board sitting on 13 June 2004. One should mention that, in accordance with the existing university internal regulations, the procedure for awarding an honoris causa doctorate by the University Senate could be commenced provided that a petition was launched in the form of a resolution passed by the board of the basic organizational unit authorized to confer the degree of habilitated doctor. In 2004, the Faculty of Theology of UMK whose dean was, as mentioned above, Rev. Professor Bagrowicz, the petitioner, did not have such authority. A relevant resolution was passed by the Board of the Faculty of Economic Sciences and Management on request of the Faculty Dean (and the author of this study), who then repeatedly had to answer the question why that and no other faculty of UMK started the procedure. The answer was simple. Surely, each faculty would treat it as great honour to put forward to the Senate a petition to grant Pope John Paul II an honoris causa doctorate of UMK. However, the Faculty of Economic Sciences and Management simply outran other university faculties. There was also an important substantial argument: The faculty had decided before to build its identity on foundations close to the Church's social teaching, to which the Holy Father John Paul II had brought extremely valuable elements. Therefore, the faculty, in its operation, reserved a prominent place for corporate social responsibility. Additionally, in its history, there was a material trace of the bond with Pope John Paul II. During his apostolic pilgrimage to Poland in 1999, while visiting Torun on 7 June, the Holy Father dedicated a cornerstone, thereby blessed the project of extending the faculty building.

The procedure for conferring an honoris causa doctorate to Pope John Paul was unprecedented at the university, as it had abandoned the requirement of receiving three positive reviews approved by senates of the schools employing the reviewers. The abandonment was justified by the exceptional greatness and prevalent worldwide acknow ledgement of the Holy Father's merits for science, culture and the international community, as a statesman being a robust defender of human rights and an advocate of freedom and peace. 


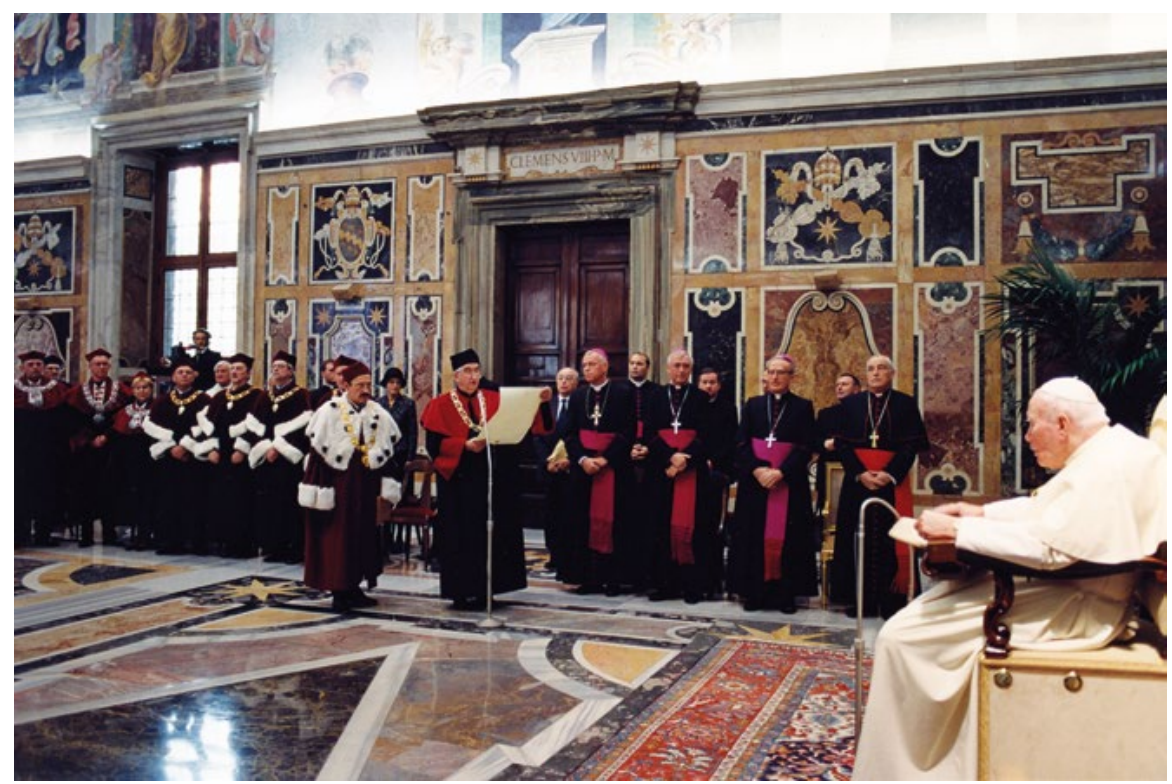

fot. Arturo Mari

On 22 June 2004, the Senate of the Nicolaus Copernicus University in Torun took an unanimous decision about awarding the Holy Father John Paul II an honoris causa doctorate.

The degree ceremony took place in the Vatican in Clementine Hallon 23 November 2003. The University Senate arrived in Rome the day before. The Senate members were accompanied by representatives of the authorities of KujawyPomerania Province and the City of Torun.

The Church dignitaries, including Cardinal Zenon Grocholewski, Prefect of the Congregation for Catholic Education and Andrzej Suski, the Bishop of Torun, took part in the ceremony.

At about 11.00 a.m. the Holy Father arrived on his throne. With the sign of the cross made with his raised hand, he greeted the gathered people who responded with a spontaneous applause. The ceremony was commenced by Bishop Andrzej Suski, thanking the Holy Father for the gift of the meeting.

The laudation was made by Professor Jan Kopcewicz, Rector of the University. Here is its content: 
"Your Holiness,

Your Eminences, Excellences,

The lofty Senate, Ladies and Gentlemen,

The Nicolaus Copernicus University in Torun is on the eve of the celebrations of its sixty years of existence. We are expressing our gratitude to You, Your Holiness, that together with You we can start the celebrations of our jubilee, being honoured by an opportunity to award You an honoris causa doctorate of our university. We were given an opportunity to include the Pope - the Pole into our academic community. Your Holiness' decision about being ready to accept the doctorate is for us both honour and duty.

The unanimous decision in this respect made by the Senate of our university expresses respect and recognition for You, the Holy Father, as the biggest authority of the contemporary world, an advocate of peace and friendship, a dedicated Polish patriot, who arouses, among the Poles, a sense of national pride and the desire for freedom.

On this unique day, we are recalling Your Holiness' meeting with representatives of the world of Polish science in that memorable afternoon on 7 June 1999. We keep reading anew the message You addressed, then, to scholars. It was just when You made us realize that where knowledge and culture are open to the sense and the truth, we are able to cross the threshold of hope and to discover again the world of these values that are crucial for science: dignity and respect for Wisdom. The universalism of Your Holiness' message, which was then sent from the Nicolaus Copernicus University in Toruń, showed unshaken hope and faith in man, whatever their history of life and ways of their own search for good. This was the time of the release of the encyclical letter Fides et ratio, talking about Faith and reason, as two wings on which the human spirit rises to the contemplation of truth. ${ }^{1}$

The Holy Father, Your call "Be not afraid" made at the beginning of Your service to the Church and the world, was addressed to all, in particular to inhabitants of the then divided Europe, also of Central and Easter Europe that wanted to free itself from the chains of ideological materialism. With love but also with the shepherd's power, You have been showing "signs of hope" we also need today. The fact that the European body slowly starts to "breathe" with both

${ }^{1}$ Cf. John Paul II, Encyclical Letter Fides et Ratio, opening words, see: http://w2.vatican. va/content/john-paul-ii/en/encyclicals/documents/hf_jp-ii_enc_14091998_fides-et-ratio.html (12.04.2019). 
[Eastern and the Western] lungs, that the cultural heritage of all European nations contributes to the life on our continent, all of this, has happened also due to Your, Holy Father's, great commitment to connecting people.

Holy Father, Your teaching, attitude and testimony has been for us, especially in difficult moments, a sign of hope and a call for a change. They let us protect our heritage and culture - the values thanks to which we felt members of the big European family and the humankind. Openness, freedom and solidarity, but also a lack of fear, and deep hope accompanying Your message, were ahead of our time and our partial thinking. "We have been «restored to ourselves»" these are the words of Your Holiness said to the public leaders of Poland in the Royal Castle of Warsaw on 8 June $1991^{2}$ - the words that made us realize the essence ofthe transformations.

Your Holiness, on behalf of the whole community of the Nicolaus Copernicus University in Toruń: professors, students, administration personnel and the staff, in the name of all those who constitute our academic community, our Alma Mater, we thank You for the power of Your word, for giving signposts for the future, and for your care for all of us. We also thank You, the Holy Father, for the opportunity to meet You today.

We trust that this meeting will strengthen our university in accomplishing its mission of service to science and society."

After the Rector's address, Rev. Professor Jerzy Bagrowicz, the Dean of the Faculty of Theology, read out the Latin text of the diploma of the honoris causa doctorate. Its Polish version reads as follows:

"The Senate decided unanimously to award His Holiness John Paul II the degree of honoris causa doctor of the Nicolaus Copernicus University in Torun in recognition of His merits for science, culture and international society. The Senate confers this degree to the Pope - the Pole as an eminent philosopher and theologian, a priest, a statesman, a defender of human rights, and an advocate of freedom and peace, the biggest authority of the contemporary world. The Senate grants this honour to John Paul II on the sixtieth anniversary of the foundation of the university and on the fifth anniversary of the Holy Father's meeting with the world of science within the walls of our Alma Mater.

2 John Paul II, Apostolic Journey to Poland: To public leaders of Poland in the Royal Castle of Warsaw (June 8, 1991), 3, see: http://w2.vatican.va/content/john-paul-ii/en/speeches/1991/ june/documents/hf_jp-ii_spe_19910608_autorita-varsavia.html (26.04.2019). 
The hall was filled with silence. After a while, the Holy Father started his speech:

\section{Dear Father Cardinal,}

Venerable Brothers in the Episcopate, The Honourable Senate Members, Eminent Representatives of the Authorities present here, Dear Brothers and Sisters!

You are warmly welcome. I am happy that I can host such distinguished representatives of the Nicolaus Copernicus University in Toruń. I thank Mr Rector for His kind words, and the Senate for awarding me the degree of honoris causa doctor. I am receiving it with gratitude as a sign of the ever developing dialogue between science and faith.

While hosting You in the Vatican, I am recalling that day of June 1999, on which I was given an opportunity to cross the doorsteps of your university. I remember I was talking then exactly about that dialogue that should overcome the Enlightenment juxtaposition of the truth discovered by reason to the truth established by faith. Today, we understand more and more that it is about the same truth and it is necessary that people, while reaching it by ways appropriate to them, will not be going alone - that they will be looking for confirmation of their own intuitions, also in meeting others. It is only then that scientists and people of culture will really be able to take this particular responsibility I was talking about in Torun - "responsibility for the truth - for pursuing it, defending it and living according to it."

I am happy that the Nicolaus Copernicus University is developing energetically, offering an opportunity to acquire knowledge to an ever growing number of young people. It is good that the Faculty of Theology can also participate in it. I know that this development is occurring with the support of the city authorities of Toruń, the city that can be easily called "a university city." Let this joint undertaking work out well for Toruń, the region and whole Poland. There is no bigger asset in a nation than its enlightened citizens.

I thank you once again for coming. Please convey my regards to all professors and students of your university, as well as to all citizens of Torun. May God's blessing be always upon you! God bless you!

The guests thanked with thunderous applause. 
In the last part of the ceremony, the Holy Father received gifts, including a book titled Fides quaerensintellectum - Faith seeking understanding, ${ }^{3}$ dedicated to the Pope by the university, and an oil painting on canvas "Crucifixion on the Tree of Life" painted in 2004 by Professor Józef Flik ${ }^{4}$ based on a $14^{\text {th }}$ century Gothic crucifix from St. James' Church in Torun. Then, the University Rector and Bishop Andrzej Suski introduced the members of the university delegation and the guests to the Holy Father.

Exactly at the same time when the Holy Father was collecting, in the Vatican, the diploma of honorary doctor, a ceremony of unveiling a stone tablet in the building of the Faculty of Economic Sciences and Management of UMK, commemorating that great event, was held in Torun. The ceremony was a symbol of the unity of the whole academic community with the Holy Father and its gratitude for his pontificate. It was attended by representatives of all faculties of the university. The Diocese of Torun was represented by Auxiliary Bishop Józef Szamocki.

In 2005, the Nicolaus Copernicus University named the building of the Faculty of Economic Sciences and Management as John Paul II Collegium.

An honoris causa doctorate is the highest distinction awarded by schools of higher education to the most eminent scholars and authors, distinguished artists, and prominent statesmen. Prior to being elected Pope, Karol Wojtyła was awarded an honoris causa doctorate by the Johannes Gutenberg University Mainz (Germany). In the term of his pontificate twelve universities awarded the Holy Father John Paul II with that distinction. These were, in chronological order: The University of Coimbra (Portugal); The University of Cambridge (the UK); The Catholic University of Lublin (Poland); The Jagiellonian University in Cracow (Poland); Franciscan University of Steubenville (the USA); AGH University of Science and Technology in Cracow (Poland); Adam Mickiewicz University in Poznań (Poland); Warsaw University of Life Sciences (Poland); Cardinal Stefan Wyszyński University in Warsaw (Poland); Sapienza University

${ }^{3}$ Fides quaerensintellectum - wiara poszukująca rozumu, ed. J. Bagrowicz, Toruń 2004.

${ }^{4}$ Józef Flik, a distinguished Polish monument expert and fine art restorer, a long-standing faculty member of the Nicolaus Copernicus University in Toruń, and in 2002-2005 the Dean of the Faculty of Fine Arts of UMK. 
of Rome (Italy); The University of Opole (Poland), and the Nicolaus Copernicus University in Torun (Poland). ${ }^{5}$ Therefore, the Nicolaus Copernicus University in Torun, being the last one that awarded an honorary doctorate to the Holy Father during his life, had an honour to express its deepest respect to his person, taking account of the full spectrum of achievements of that Greatest of All Great Poles, and to thank him for everything he had done for our homeland and the world, as well as for science and culture.

${ }^{5}$ The data comes from information provided by the Holy See. 